\title{
Modelling mould growth risk in English social housing
}

\author{
Xuanchen $\mathrm{Ge}^{\mathrm{a}}$, Jonathon Taylor ${ }^{\mathrm{a}, \mathrm{b}^{*}}$, Sofie Pelsmakers ${ }^{\mathrm{b}}$, Raúl Castaño ${ }^{\mathrm{b}, \mathrm{c}}$ \\ aUniversity College London, London, UK \\ bTampere University, Tampere, Finland \\ c University Carlos III of Madrid, Madrid, Spain
}

\begin{abstract}
Social housing may be at increased risk of damp and subsequent mould growth due to housing characteristics such as poor ventilation and energy efficiency, and occupant fuel poverty. In this study, surface relative humidity and temperature are estimated in flats in a typical low-rise multi-dwelling building in London using the EnergyPlus Heat and Moisture Transport (HAMT) model under different occupant activities. Mould Growth Index (MI) is then estimated using this data. Results indicate that MI is highly influenced by the amount of moisture generated indoors, indoor heating schedule, outdoor climate, and the floor level. Local governments should ensure that residents of social housing have sufficient access to affordable heating and extract fans to reduce mould exposure risk.

Peer-review under the responsibility of the organizing committee of the ICMB21.
\end{abstract}

Keywords: Mould, social housing, damp, hygrothermal models

\section{Introduction}

Social housing in England are provided by housing associations or local councils at reduced rents to low-income households. It currently comprises $17.3 \%$ of the English housing stock and can be home to some of the most vulnerable members of society, including many who may suffer from fuel poverty and cannot adequately heat their homes [1], [2]. Occupiers of social housing experience problems with their housing - such as cold and damp - more often than owner-occupiers [3]. Social housing has poor levels of background ventilation relative to the wider stock and are more likely to have broken or missing extract fans in kitchens and bathrooms [4]. Finally, low-income individuals are more likely to live in overcrowded dwellings, have a lower perception of the risk of damp and mould [1], are less likely to own a tumble dryer [5], and can on-average spend more time cooking [6] which may generate moisture. Consequently, social housing may be at increased risk of indoor damp and mould growth. In this paper, we aim to quantify the changes in mould growth risk in typical English social housing under different housing and behavioural scenarios using a building simulation approach.

\section{Methods}

An archetype representative of a typical English low-rise flat [7] was modelled, as it is a common form of social housing in London. The building simulation tool EnergyPlus [8] was used due to the ability to dynamically model indoor temperatures, as well as moisture transport in the building envelope using the Heat and Moisture Transport (HAMT) algorithm. This includes moisture from indoor and outdoor sources, excluding driving rain which the HAMT is not yet able to model. The building was modelled with a $0.21 \mathrm{~m}$ solid brick external wall with internal gypsum, internal partition walls of timber and gypsum, solid concrete slab internal floors with gypsum ceiling, and an uninsulated pitched roof; hygroscopic material information was taken from the WUFI database [9]. Ventilation occurs passively through a permeable building fabric $\left(10 \mathrm{~m}^{3} / \mathrm{h} / \mathrm{m}^{2}\right)$ and through extract fans in the kitchen and bathroom operating to UK building regulations. Flats were modelled at ground, middle, and top floors.

Occupancy assumptions were based on those of a couple at home during the day [7]. Indoor moisture sources included cooking, showering, and drying laundry; schedules for these activities were taken from previous simulation studies [7], while laundry was assumed to happen three days a week with indoor hang drying lasting all day. Moisture emission rates were taken from the Chartered Institution of Building Services Engineers (CIBSE) Guide A [10], modelled as the fraction of energy emitted as latent heat. Model variants included a reduced set of hours with space heating (4.8 hours vs 12 hours a day), broken extract fans, and building orientation. Outdoor weather conditions were modelled based on a typical year at Gatwick airport. Hourly internal surface relative humidity $(\mathrm{RH})$ and temperature were output from the model and used to calculate the Mould Growth Index (MI) using the model developed by Viitanen et al [11] in Excel during a post-processing step.

\footnotetext{
* Corresponding author. jonathon.taylor@tuni.fi
} 
ICMB21

\section{Results and discussion}

Example results of the model can be seen in Figure 1. Key results are:

- Ground floor flats are more susceptible to mould growth than flats on other floors. This is due to the lower temperatures, caused by less solar exposure and heat loss through the stack effect. Social housing providers should ensure low temperatures are not exasperated by, for example, reduced solar gains due to shading from vegetation. North-facing ground floor areas may be better suited for storage or facilities than housing.

- The MI was greater on the internal faces of external walls, particularly during winter, due to the colder surface temperatures. Energy efficient retrofit can help reduce heat transfer through the walls, although solid wall internal insulation poses additional interstitial mould growth risks. The HAMT model is unable to account for driving rain, which means this risk may be underestimated, particularly in exposed buildings.

- Reducing heating to 4.8 hours a day substantially increased the MI. For example, in ground floor bathrooms the peak annual MI increased from around 1 (microscopic mould growth) to 4 (10-50\% coverage of visible mould) with insufficient heating.

- Indoor drying of laundry was a significant moisture source $(1.9 \mathrm{~kg} /$ day $)$ that often isn't accompanied by compensatory extract ventilation to remove damp air. This led to a peak MI of 3 (10-50\% coverage of microscopic mould) in living rooms during the winter; similar to the bathroom and more than the kitchen. Social housing providers should therefore make provisions for outdoor drying of clothing or communal tumble dryers.

- $\quad$ MI risk was also increased significantly without working extract fans, particularly in middle and top floor flats. Only around $45 \%$ of low-income households in England have working extract fans [4], so housing providers should ensure that extract fans are functional and exhaust outside. This would also help reduce indoor air pollution which may be higher in low income housing [12].

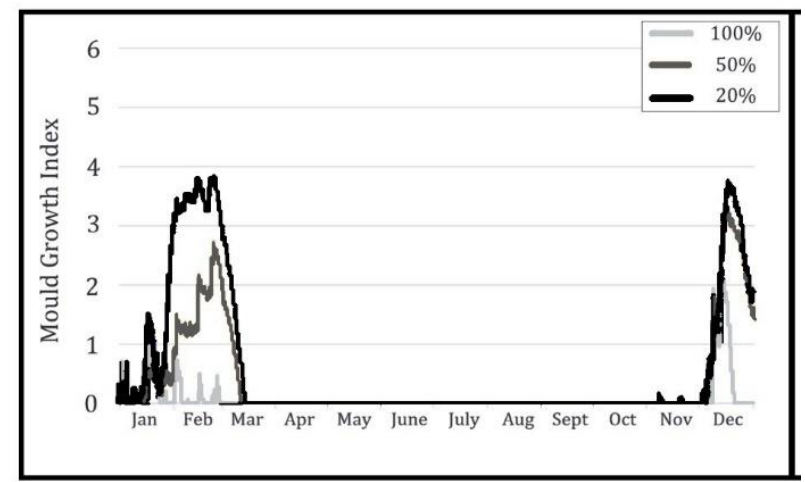

Figure 1. (a) The mould growth index for a ground floor bathroom with different heating regimes in a poorly insulated flat.

\section{References}

[1] Sharpe, R. A., Thornton, C. R., Nikolaou, V., \& Osborne, N. J. (2015) Fuel poverty increases risk of mould contamination, regardless of adult risk perception \& ventilation in social housing properties, Environment International, 79, 115-129

[2] Boomsma, C., Pahl, S., Jones, R. V., \& Fuertes, A. (2017) 'Damp in bathroom. Damp in back room. It's very depressing!' exploring the relationship between perceived housing problems, energy affordability concerns, and health and well-being in UK social housing. Energy Policy, 106, 382-393.

[3] Pevalin, D. J., Taylor, M. P., \& Todd, J. (2008) The Dynamics of Unhealthy Housing in the UK: A Panel Data Analysis, Housing Studies, 23(5) 679695.

[4] Shrubsole, C., Taylor, J., Das, P., Hamilton, I. G., Oikonomou, E., \& Davies, M. (2016) Impacts of energy efficiency retrofitting measures on indoor PM2.5 concentrations across different income groups in England: a modelling study. Advances in Building Energy Research, 10(1) 69-83.

[5] Gregg, P., Waldfogel, J., \& Washbrook, E. (2006) Family expenditures post-welfare reform in the UK: Are low-income families starting to catch up?,” Labour Economics, 13(6) 721-746.

[6] Adams, J. \& White, M. (2015) Prevalence and socio-demographic correlates of time spent cooking by adults in the 2005 UK Time Use Survey. Crosssectional analysis, Appetite, 92, 185-191.

[7] Taylor, J., Davies, M., Mavrogianni, A., Shrubsole, C., Hamilton, I., Das, P., ... \& Biddulph, P. (2016) Mapping indoor overheating and air pollution risk modification across Great Britain: A modelling study, Building and Environment, 99, 1-12.

[8] US DOE (2013) EnergyPlus V8. United States Department of Energy, Washington, D.C.

[9] Fraunhofer Institute for Building Physics (2007) WUFI-2D, PC-Program for calculating the coupled heat and moisture transfer in building components. IBP, Stuttgart, Germany.

[10] CIBSE. (2015) CIBSE Guide A: Environmental Design, Chartered Institution of Building Services Engineers, London, UK.

[11] Viitanen, H., \& Ojanen, T. (2007) Improved model to predict mold growth in building materials. In Proceedings of the 10th Thermal Performance of the Exterior Envelopes of Whole Buildings Conference, Dec 2-7, 2007, Atlanta, USA.

[12] Ferguson, L., Taylor, J., Davies, M., Shrubsole, C., Symonds, P., \& Dimitroulopoulou, S. (2020) Exposure to indoor air pollution across socioeconomic groups in high income countries: A scoping review of the literature and a modelling methodology, Environment International, vol. 140, p. 105748 . 